\title{
Como você começou? A iniciação musical de quatro ícones damúsica paraense
}

\section{How did you start? The musical initiation of four icons of paraense music.}

DOI: $10.46814 / \operatorname{lajdv} 3 n 4-012$

Recebimento dos originais: 01/05/2021

Aceitação para publicação: 31/06/2021

Júlio Cesar Vicari

UNAMA

E-mail: juliovicari@hotmail.com

\section{Erasmo Borges De Souza Filho \\ UFPA \\ E-mail: efilho90@hotmail.com}

Para a elaboração desse artigo, a produção do documentário Música no Pará, que será um produto realizado após a conclusão da dissertação de mestrado na qual esta pesquisa faz parte, iniciou em 2013, com o registro audiovisual de várias entrevistas, sendo essas apenas uma parte, com profissionais como cantores, músicos, produtores e técnicos regionais. Essas entrevistas resultaram em um material extenso, com uma gama de informação enorme, dificultando, emprimeira análise, identificar em cada resposta, o momento exato em vídeo, a frase ou a palavra que significasse a realidade e a verdade buscada para a realização do filme. Esta identificação énecessária pois seria impossível utilizar todo o conteúdo registrado que resultaria em um filme com muitas horas de duração. Em meio a essa dificuldade, encontrou-se uma forma de analisar o conteúdo de cada resposta, identificando o momento ou os momentos exatos em que o entrevistado globalize todos os significados proferidos, possível de interpretação pelo público que assistirá ao produto. Através dos estudos baseados nos conceitos semióticos proferidos por Greimas, percebeu- se a possibilidade de, através da análise discursiva, analisar e identificar as oposições semânticas definindo o discurso. Com essa possibilidade, pode-se criar um roteiro de edição e montagem para ofilme. O objetivo dessa pesquisa é criar uma ferramenta que viabilize a análise discursiva de questionamentos e respostas registrados em entrevistas, onde o método utilizado será um estudo exploratório de natureza qualitativa, compreendendo entrevistas de profundidade com especialistas, buscando assim descobrir o motivo principal que possibilitou, incentivou ou permitiu o início da carreira musical dos entrevistados. A principal utilidade das entrevistas de profundidade é a pesquisa exploratória, que proporciona análise pessoal e entendimento. As entrevistas foram realizadas pelo próprio pesquisador, individualmente ou com grupos de pessoas que formam um grupo musical, seguindo um roteiro preestabelecido cujos dados foram registrados em audiovisual. 
Palavras-chave: Semiótica, Música Paraense, Análise Discursiva.

Link Documentário: vimeo.com/231548587 